\section{Australian Journal of \\ Crop Science}

AJCS 14(02):263-270 (2020)

doi: 10.21475/ajcs.20.14.02.p2121

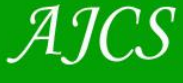

ISSN:1835-2707

\title{
Estimation of adaptability and stability of early strains of 'Carioca' and black beans (Phaseolus vulgaris) in Pernambuco State, Brazil
}

\author{
Richardson Sales Rocha ${ }^{1}$, Paulo Ricardo dos Santos ${ }^{1}$, Tâmara Rebecca Albuquerque de Oliveira ${ }^{1}$, Rogério \\ Figueiredo Daher ${ }^{1}$, Maxwel Rodrigues Nascimento ${ }^{1}$, Alexandre Gomes de Souza ${ }^{1}$, Larissa Jaina da Silva de \\ Oliveira $^{1}$, Katiane da Rosa Gomes da Silva ${ }^{2}$, Kleyton Danilo da Silva Costa ${ }^{3}$, Antônio Félix da Costa ${ }^{2}$, Helton \\ Pereira Santos ${ }^{4}$
}

\author{
${ }^{1}$ Universidade Estadual do Norte Fluminense Darcy Ribeiro, Centro do Ciências e Tecnologias Agropecuárias, \\ Avenida Alberto Lamego, no 2000, Parque Califórnia, CEP 28013-602, Campos dos Goytacazes, RJ, Brazil \\ ${ }^{2}$ Instituto Agronômico de Pernambuco (IPA), Avenida General San Martin, no 1371, Bongi, CEP 50761-000, Recife, \\ PE, Brazil \\ ${ }^{3}$ Instituto Federal de Educação, Ciência e Tecnologia de Alagoas (IFAL), Avenida Sergipe, s/no, Xingó, CEP 57460-000, \\ Piranhas, AL, Brazil \\ ${ }^{4}$ Empresa Brasileira de Pesquisa Agropecuária (Embrapa Arroz e Feijão), Rodovia GO 462, km 12, s/no, CEP $75375-$ \\ 000, Santo Antônio de Goiás, GO, Brazil
}

\begin{abstract}
Low yields of early 'Carioca' and black bean varieties are a consequence of instability and low yield adaptability to specific growing environments. The goal of this work was to evaluate the genotype $\mathrm{x}$ environment interaction of early 'Carioca' and black bean new lines aiming at obtaining genotypes with high grain yield and good adaptability and stability. In (2012), 15 genotypes of the black group were evaluated in Ibimirim, Belém do São Francisco, and Petrolina municipalities, in Pernambuco State, Brazil; and, in (2016), 11 genotypes of early 'Carioca' bean were evaluated in Caruaru, Arcoverde, and Araripina municipalities, also in Pernambuco State. The experiment was conducted in a randomized block design with three replicates, and grain yield data were submitted to analysis of variance, in which means were compared by the Tukey's test and analysis via GGE Biplot. In Arcoverde, the grain yield was greater for all early 'Carioca' bean genotypes, whereas, in the environment of Petrolina, there was the worst grain yield in $\mathrm{kg}^{-1}$ for all black bean genotypes, individually. The GGE Biplot methodology was found to be efficient in identifying genotypes with good adaptability, stability, and yield. Differences presented by the genotypes for the grain yield trait give the basis to recommend the genotypes and express the possibility of selection for genetic improvement of the species.
\end{abstract}

Keywords: common bean, genotypes in vivo, new cultivars, simultaneous selection, yield.

Introduction

As estimated by the Companhia Nacional de Abastecimento - Conab (National Food Supply Company), Brazil recorded, in May 2019, a total area of 2,977.7 mil ha of bean cultivation, with a yield of $1,042 \mathrm{~kg} / \mathrm{ha}$, and production of 3,104.3 mil t (Conab, 2019). Not only is the country the largest producer of this grain, it is the largest consumer of it, with $17 \mathrm{~kg} /$ year per inhabitant, corresponding to 3.52 mil t per year (Silva and Wander, 2013, FAO, 2015). Also, in May 2019, the growing of total black common beans was responsible for $10.7 \mathrm{mil} \mathrm{ha}$ of cultivated area, $638 \mathrm{~kg} / \mathrm{ha}$ of yield, and $6.8 \mathrm{mil}$ $t$ of production in the Pernambuco State. With regard to the total 'Carioca' common beans, Pernambuco State has 88.9 mil ha of cultivated area, $603 \mathrm{~kg} / \mathrm{ha}$ of yield, and $53.6 \mathrm{mil}$ t of production (Conab, 2019).

In Pernambuco State, bean crop is grown in different areas with contrasting edaphoclimatic characteristics, causing significant effects on grain yield of common bean. In accordance with Barros et al., (2013), many abiotic problems that affect bean crop yields should be taking into account by breeding programs, so that producers adopt the best decisions.

Black beans and 'Carioca' beans have a cycle that varies from 85 to 95 days, usually cultivated in the 1st season of the year (harvest of water) in the Pernambuco State. It stands out for being more sensitive to environmental variations (Rosse and Vencovsky, 2000). Sudden climatic changes cause changes in grain yield (Paranzini et al., 2009). The predicted conditions, such as climate, soil, and agronomic techniques, and unpredictable, as rainfall distribution, temperature, soil, and frost, contribute directly to the interaction $\mathrm{G} \times \mathrm{A}$ (Paranzini et al., 2009).

Therefore, the development of new cultivars with favorable alleles for the traits of interest is necessary to meet the needs of rural producers (Coimbra et al., 2008). Nevertheless, the interaction genotype $x$ environment (GxE) in the phenotypic constitution of a character is a problem for the breeder, whose goal is to select genotypes with greater 
yield, adaptability, and stability (Ribeiro et al., 2008; Bertoldo et al., 2009).

In accordance with Vale et al. (2009), the component of the genotype $x$ environment interaction is able to prove that a genotype that presents vitality and productivity in a certain environment may not show the same performance when cultivated in another environment. For this reason, after developing lines, they should be tested in different environments (Torres et al., 2015). Within this context, the development of a plant breeding program focused on obtaining adapted bean lines with high stability is justified, as they can significantly improve yield systems.

A number of methods enables the estimation of adaptability and stability of genotypes based on different principles (Eberhart and Russel 1966, Verma et al., 1978, Lin \& Binns 1988, Cruz et al., 1989). Nevertheless, the GGE Biplot methodology is distinguished for being a versatile and flexible analysis allowing the selection of genotypes by means of graphical representations in an easy and efficient way (Badu-Apraku et al., 2012, Yan, 2014).

The efficiency of this methodology in selecting genotypes with good adaptability and stability has been validated in different crops (Paramesh et al, 2016, Yokomizo et al., 2017, Oliveira et al., 2018). In view of that, this work intended to evaluate the adaptability and stability of early strains of 'Carioca' and black bean in Pernambuco State, Brazil.

\section{Results and Discussion}

\section{Analysis of variance}

The 'Carioca' group experiment had a good precision, with a coefficient of variation below 15 percent; for the black group, the coefficient of variation was between 18.19 and 32.12 percent, representing, respectively, medium and low experimental precision (Carbonell et al., 2010; Pereira et al., 2018). Results of the analysis of variance demonstrated significant effects for genotypes and environments suggesting the presence of genetic variability between bean lines and edaphoclimatic differences between environments, in this order (Table 1). The significance of genotypes $x$ environments interaction proves that the lines presented distinguished performances regarding environmental changes (Torres Filho et al., 2017).

With regard to plant breeding, it is essential, for the selection of superior phenotypes, to have previous knowledge of the contribution of each of the components of variance. The value found in the estimate of the coefficient of genotypic determination $\left(\mathrm{H}^{2} \%\right)$ for 'Carioca' bean was of 90.95, 94.62, and 95.01 percent, in the Araripina, Caruaru, and Arcoverde environments, respectively. Nevertheless, it is perceived that there is a greater additive genetic variance and a smaller environmental variation when there is a higher coefficient of genotypic determination, proving that the environment had a small influence on the characters under study.

For the black group, the value found in the estimate of the coefficient of genotypic determination was superior for Ibimirim (77.11\%), Petrolina (73.25\%), and Belém do São Francisco $(54.41 \%)$ environments. The coefficients of genotypic determination were considered as medium for Belém de São Francisco environment and high for the other ones.

\section{Mean test}

The highest grain yields, in Araripina, were obtained by the BRS Notável control and the CNFC 15502, CNFC 15874, CNFC 15873, and CNFC 15625 lines, respectively (Table 2). With the exception of the CNFC 15625, these lines also showed yields above the overall mean in the Caruaru municipality, together with the CNFC 15875 line. The good performance of the CNFC 15502 line in Caruaru is different from the results found by Watanabe (2014). Regarding the Arcoverde, the highest yield means were obtained by the CNFC 15626, CNFC 15874, BRS Notável, IPR Colibri, CNFC 15625 lines, respectively.

Generally speaking, the CNFC 15874 line and the BRS Notável control adapted well in all three environments, being among the ones that provided yields above the overall mean. It is worth pointing out that the CNFC 15874 had a higher mean than the IPR Colibri and early 'Carioca' controls in the three environments under evaluation. With respect to the black bean commercial group, the CNFP 10104, CNFP 10794, CNFP 15171, CNFP 15178, CNFP 15193, and CNFP 15207 lines presented yield above the overall mean in Ibimirim, being superior to the three controls. The ones which had the worst yields are the CNFP 15198, CNFP 15208, and the Esplendor control.

In Belém do São Francisco, the CNFP 15171, CNFP 15178, CNFP10104, CNFP 15177, IPR Uirapuru, CNFP 15198, and CNFP 15208 lines had higher grain yields, respectively. The CNFP 15208 provided the worst yield in Petrolina, significantly different from the CNFP 15194 line, which had the highest yield, with $1344.16 \mathrm{~kg} / \mathrm{ha}^{-1}$, in this environment. The other lines, which showed yields above the mean, were BRS Campeiro, CNFP 15171, CNFP 10104, CNFP 15194, and BRS Esplendor.

It can be noted that the Ibimirim environment was the one that provided the highest grain yield means followed by the Belém do São Francisco environment, in which only CNFP 10794 and CNFP 15193 lines performed the worst yields. The smallest means were obtained by the Petrolina environment. Statistically, when comparing the environments, it could be seen that only the BRS Campeiro control and the CNFP 15194 genotype behaved the same way in yield in the three environments.

\section{GGE Biplot analysis}

\section{Which-won-where}

The Biplot analysis of genotypes $x$ environment (GGE Biplot) showed 95.79 and 78.01 percent of the total variation for the 'Carioca' and black group, in this order (Figure 1). These results reveal the efficiency of the Biplot graphs, which explained the large proportions of the square sums of genotypes and the genotype $x$ environment interactions, enabling an accurate understanding of the results and reliability to select superior genotypes (Oliveira et al., 2018). The which-won-where Biplot establishes a set of perpendicular lines, which divide it into a number of groups, defining that the lines with the best performance are those located at the Biplot vertices, which grouped at least one 
Table 1. Analysis of variance for grain yield variable (kg.ha-1) of 11 genotypes of 'Carioca' bean group in 2016 crop year and 15 genotypes of the black group in 2012 crop year, evaluated in different environments in Pernambuco State.

\begin{tabular}{|c|c|c|c|c|}
\hline \multicolumn{5}{|c|}{---------------Early 'Carioca' Bean---------------------- } \\
\hline VS & DF & MS & $\mathrm{CV} \%$ & $\mathrm{H}^{2} \%$ \\
\hline Block/Environment & 6 & 8476.18 & & \\
\hline Environment (E) & 2 & $17964034.63^{* *}$ & & \\
\hline Genotype (G) & 10 & $240470.48^{* *}$ & & \\
\hline $\mathrm{G} \times \mathrm{E}$ Interaction & 20 & $113180.66^{* *}$ & & \\
\hline Araripina & 10 & $7566.38^{* *}$ & 14.82 & 90.95 \\
\hline Caruaru & 10 & $5353.70^{* *}$ & 8.66 & 94.62 \\
\hline Arcoverde & 10 & $14165.81^{* *}$ & 6.02 & 95.01 \\
\hline Residue & 60 & 9028.63 & & \\
\hline Mean & & 1135.12 & & \\
\hline CV\% & & 8.37 & & \\
\hline \multicolumn{5}{|l|}{$Q M R_{\max } / Q M R_{\min }=2.64$} \\
\hline \multicolumn{5}{|c|}{ 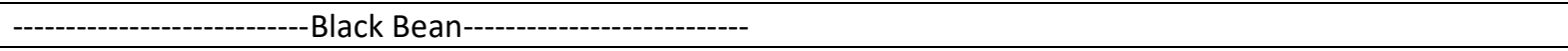 } \\
\hline VS & DF & MS & $\mathrm{CV} \%$ & $\mathrm{H}^{2} \%$ \\
\hline Block/Environment & 6 & 608026.01 & & \\
\hline Environment $(E)$ & 2 & $14402964.62^{* *}$ & & \\
\hline Genotype (G) & 14 & $344053.51^{* *}$ & & \\
\hline $\mathrm{G} \times \mathrm{A}$ Interaction & 28 & $310201.13^{* *}$ & & \\
\hline Ibimirim & 14 & $489886.60^{* *}$ & 18.19 & 77.11 \\
\hline Belém do São Francisco & 14 & $213458.33^{* *}$ & 17.72 & 54.41 \\
\hline Petrolina & 14 & $261110.85^{* *}$ & 32.12 & 73.25 \\
\hline Residue & 84 & 93100.52 & & \\
\hline Mean & & 1474.18 & & \\
\hline CV\% & & 20.69 & & \\
\hline$Q M R_{\max } / Q M R_{\min }=1.60$ & & & & \\
\hline
\end{tabular}

${ }^{*}$ Significance at $5 \%$ error probability by the $\mathrm{F}$ test. ${ }^{* *}$ Significance at $1 \%$ error probability by the $\mathrm{F}$ test. $\mathrm{H}^{2} \%$.
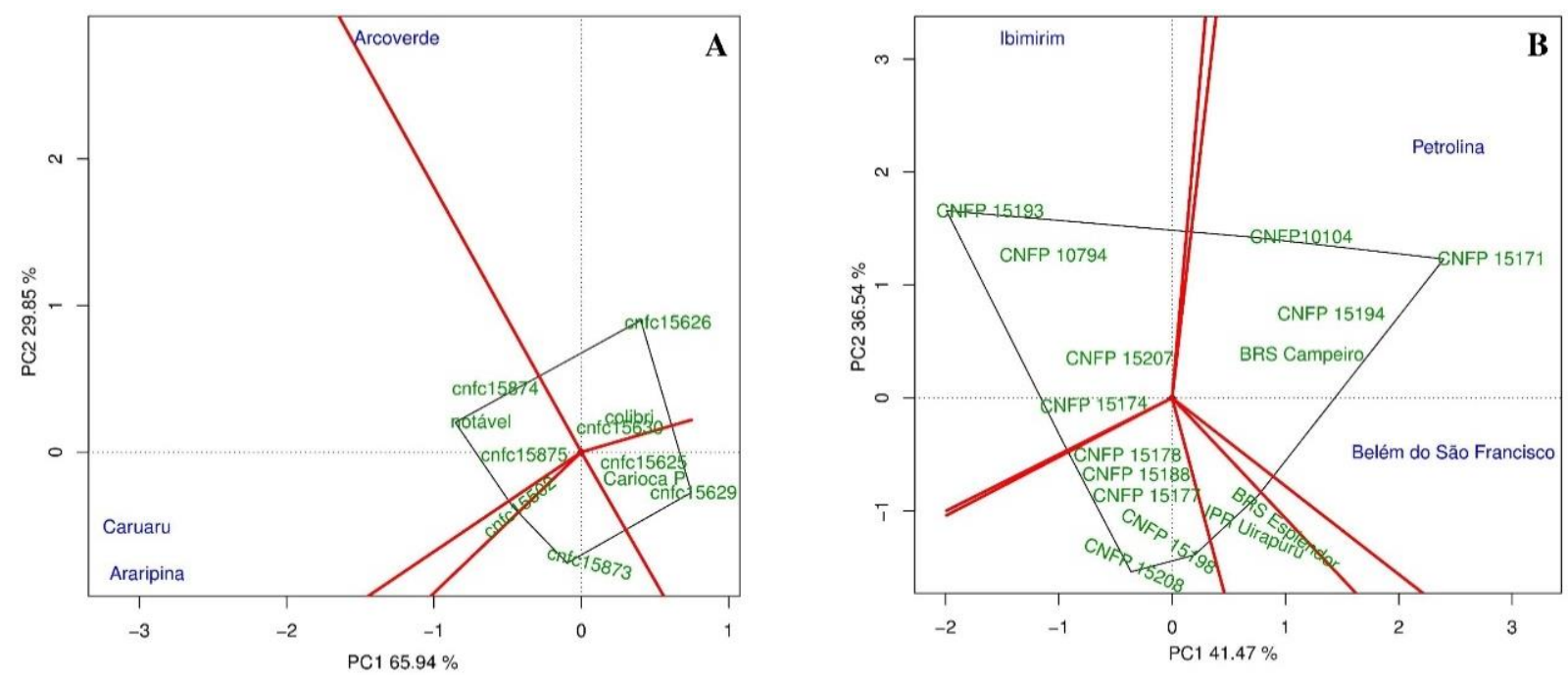

Fig 1. (A) GGE biplot representing: "Which-won-where". Genotypes: IPR Colibri, CNFC 15626, CNFC 15873, CNFC 15874, CNFC 15502, CNFC 15875, CNFC 15629, BRS Notável, CNFC 15630, Early 'Carioca', and CNFC 15625. Environments: Arcoverde, Caruaru, and Araripina. (B) Genotypes: BRS Esplendor, BRS Campeiro, IPR Uirapuru, CNFP10104, CNFP 10794, CNFP 15171, CNFP 15174, CNFP 15177, CNFP 15178, CNFP 15188, CNFP 15193, CNFP 15194, CNFP 15198, CNFP 15207, and CNFP 15208. Environments: Ibimirim, Belém do São Francisco, and Petrolina. 
Table 2. Mean test for the grain yield variable $\left(\mathrm{kg} \cdot \mathrm{ha}^{-1}\right)$ of 11 genotypes of early 'Carioca' bean group and 15 genotypes of black bean group, cultivated in three environments.

\begin{tabular}{|c|c|c|c|}
\hline \multicolumn{4}{|c|}{ 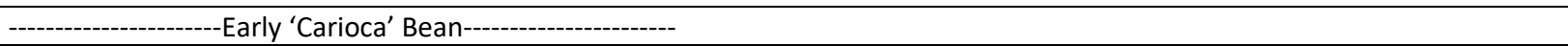 } \\
\hline Genotypes & Araripina & Caruaru & Arcoverde \\
\hline IPR Colibri & $524.16 \mathrm{C} \mathrm{bcd}$ & $741.66 \mathrm{~B} \mathrm{~cd}$ & 2031.66 A bc \\
\hline CNFC15626 & $321.66 \mathrm{Cd}$ & $657.50 \mathrm{~B} \mathrm{~cd}$ & $2465.83 \mathrm{~A} \mathrm{a}$ \\
\hline CNFC15873 & $694.16 \mathrm{C}$ ab & $911.66 \mathrm{~B}$ abc & $1691.66 \mathrm{~A} \mathrm{e}$ \\
\hline CNFC15874 & $725.00 \mathrm{~B}$ ab & 893.33 B abc & $2350.00 \mathrm{~A} \mathrm{a}$ \\
\hline CNFC15502 & $810.83 \mathrm{Ca}$ & $1117.50 \mathrm{~B} \mathrm{a}$ & 1915.83 A cde \\
\hline CNFC15875 & $497.50 \mathrm{C} \mathrm{bcd}$ & 1009.16 B ab & $1898.33 \mathrm{~A} \mathrm{cde}$ \\
\hline CNFC15629 & $368.33 \mathrm{C} \mathrm{cd}$ & $598.33 \mathrm{Bd}$ & $1385.83 \mathrm{Af}$ \\
\hline BRS Notável & $835.83 \mathrm{Ca}$ & $1123.33 \mathrm{~B} \mathrm{a}$ & $2240.00 \mathrm{~A} \mathrm{ab}$ \\
\hline CNFC15630 & $530.00 \mathrm{Cbcd}$ & 811.66 B bcd & $1746.66 \mathrm{~A}$ de \\
\hline Early 'Carioca' & $538.33 \mathrm{C} \mathrm{bcd}$ & 760.66 B bcd & $1972.50 \mathrm{~A} \mathrm{~cd}$ \\
\hline CNFC15625 & $607.50 \mathrm{~B}$ abc & $667.50 \mathrm{~B} \mathrm{~cd}$ & $2015.00 \mathrm{~A} \mathrm{bc}$ \\
\hline Mean & 586.66 & 844.75 & 1973.93 \\
\hline \multicolumn{4}{|c|}{ 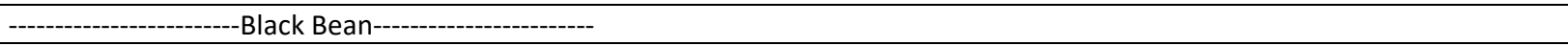 } \\
\hline Genotypes & Ibimirim & Belém do São Francisco & Petrolina \\
\hline BRS Esplendor & $1196.66 \mathrm{AB}$ e & $1716.66 \mathrm{~A} \mathrm{ab}$ & $1045.83 \mathrm{~B} \mathrm{ab}$ \\
\hline BRS Campeiro & $1622.50 \mathrm{~A}$ bcde & $1658.33 \mathrm{~A} \mathrm{ab}$ & 1224.16 A ab \\
\hline IPR Uirapuru & 1537.50 A bcde & $1858.33 \mathrm{~A} \mathrm{ab}$ & $720.00 \mathrm{~B}$ ab \\
\hline CNFP10104 & $2251.66 \mathrm{~A}$ abc & $1908.33 \mathrm{~A} \mathrm{ab}$ & $1148.33 \mathrm{~B}$ ab \\
\hline CNFP 10794 & $2399.16 \mathrm{~A} a b$ & $1383.33 \mathrm{~B} \mathrm{~b}$ & $790.83 \mathrm{~B}$ ab \\
\hline CNFP 15171 & $2222.50 \mathrm{~A}$ abcd & $2466.66 \mathrm{~A} \mathrm{a}$ & $1213.33 \mathrm{~B}$ ab \\
\hline CNFP 15174 & 1828.33 A abcde & $1566.66 \mathrm{~A} \mathrm{~b}$ & $589.16 \mathrm{~B}$ ab \\
\hline CNFP 15177 & 1767.50 A abcde & $1883.33 \mathrm{~A} \mathrm{ab}$ & $529.16 \mathrm{~B}$ ab \\
\hline CNFP 15178 & 1935.00 A abcde & $1925.00 \mathrm{~A} a b$ & $486.66 \mathrm{~B}$ ab \\
\hline CNFP 15188 & $1670.00 \mathrm{~A}$ bcde & $1691.66 \mathrm{~A} \mathrm{ab}$ & $640.83 \mathrm{~B} \mathrm{ab}$ \\
\hline CNFP 15193 & $2633.33 \mathrm{~A} \mathrm{a}$ & $1300.00 \mathrm{~B} \mathrm{~b}$ & $726.66 \mathrm{~B}$ ab \\
\hline CNFP 15194 & 1697.50 A bcde & $1733.33 \mathrm{~A} \mathrm{ab}$ & $1344.16 \mathrm{~A} \mathrm{a}$ \\
\hline CNFP 15198 & 1373.33 A de & $1850.00 \mathrm{~A} \mathrm{ab}$ & $625.83 \mathrm{~B}$ ab \\
\hline CNFP 15207 & 2025.00 A abcde & $1683.33 \mathrm{~A} \mathrm{ab}$ & $790.83 \mathrm{~B}$ ab \\
\hline CNFP 15208 & 1440.00 A cde & $1775.00 \mathrm{~A} \mathrm{ab}$ & $462.50 \mathrm{~B} \mathrm{~b}$ \\
\hline Mean & 1839.99 & 1759.99 & 822.55 \\
\hline
\end{tabular}
significance.
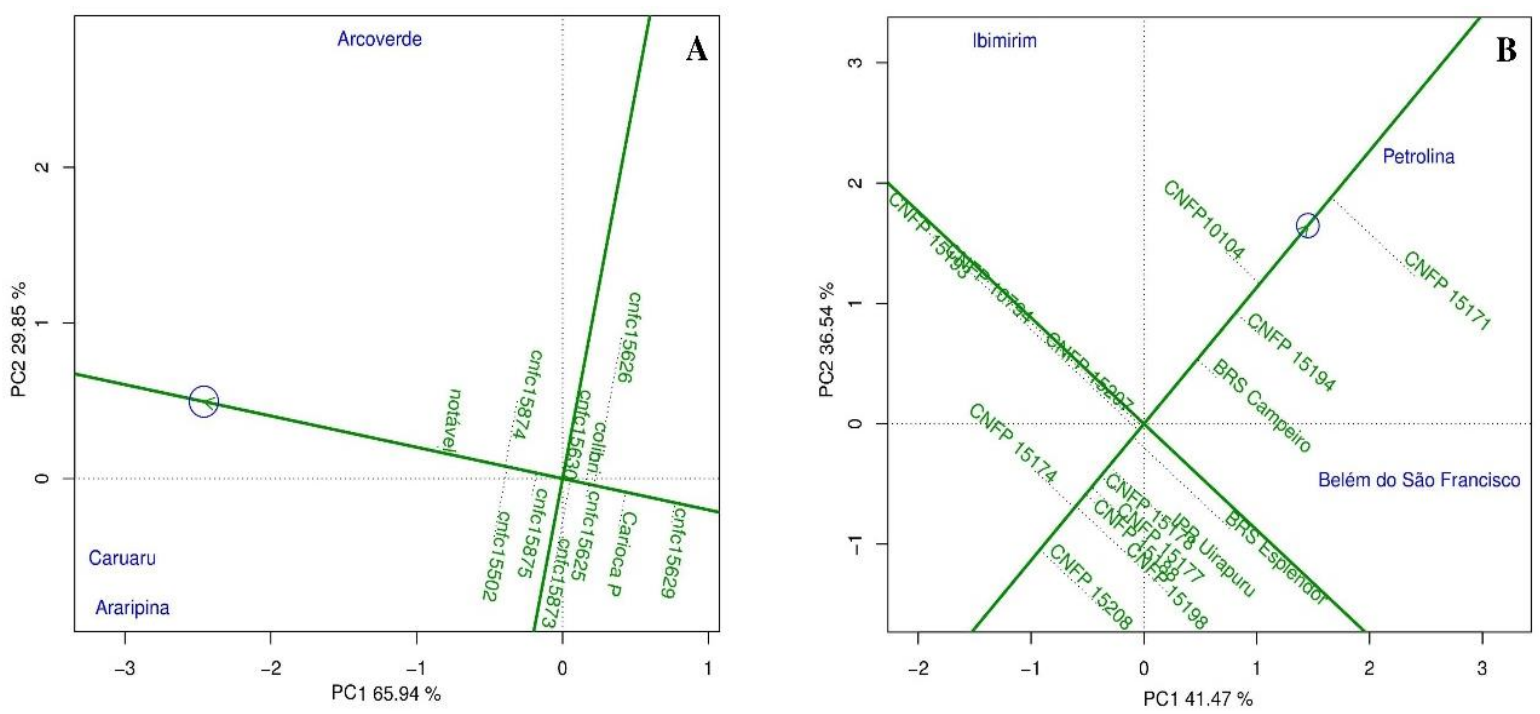

Fig 2. (A) GGE Biplot representing the Means $x$ stabilities. Genotypes: IPR Colibri, CNFC 15626, CNFC 15873, CNFC 15874, CNFC 15502, CNFC 15875, CNFC 15629, BRS Notável, CNFC 15630, Early 'Carioca', and CNFC 15625. Environments: Arcoverde, Caruaru, and Araripina. (B) Genotypes: BRS Esplendor, BRS Campeiro, IPR Uirapuru, CNFP10104, CNFP 10794, CNFP 15171, CNFP 15174, CNFP 15177, CNFP 15178, CNFP 15188, CNFP 15193, CNFP 15194, CNFP 15198, CNFP 15207, and CNFP 15208. Environments: Ibimirim, Belém do São Francisco, and Petrolina. 
Table 3. Description of the 11 genotypes of the early and semi-early 'Carioca' group evaluated in Caruaru, Arcoverde, and Araripina (2016) and of the 15 genotypes of the black group evaluated in Ibimirim, Belém de São Francisco, and Petrolina (2012).

\begin{tabular}{llllll}
\hline Early 'Carioca' Bean & Cycle & Origin & Black Bean & Cycle & Origin \\
\hline IPR Colibri & Early $^{*}$ & lapar & BRS Esplendor & Normal $^{* * *}$ & Embrapa \\
CNFC 15626 & Early & Embrapa & BRS Campeiro & Normal & Embrapa \\
CNFC 15873 & Early & Embrapa & IPR Uirapuru & Normal & Iapar \\
CNFC 15874 & Early & Embrapa & CNFP10104 & Normal & Embrapa \\
CNFC 15502 & Semi-early ${ }^{* *}$ & Embrapa & CNFP 10794 & Normal & Embrapa \\
CNFC 15875 & Early & Embrapa & CNFP 15171 & Normal & Embrapa \\
CNFC 15629 & Early & Embrapa & CNFP 15174 & Normal & Embrapa \\
BRS Notável & Semi-early & Embrapa & CNFP 15177 & Normal & Embrapa \\
CNFC 15630 & Early & Embrapa & CNFP 15178 & Normal & Embrapa \\
Early 'Carioca' & Early & Embrapa & CNFP 15188 & Normal & Embrapa \\
CNFC 15625 & Early & Embrapa & CNFP 15193 & Normal & Embrapa \\
- & - & - & CNFP 15194 & Normal & Embrapa \\
- & - & - & CNFP 15198 & Normal & Embrapa \\
- & - & - & CNFP 15207 & Normal & Embrapa \\
- & - & - & CNFP 15208 & Normal & Embrapa \\
\hline
\end{tabular}
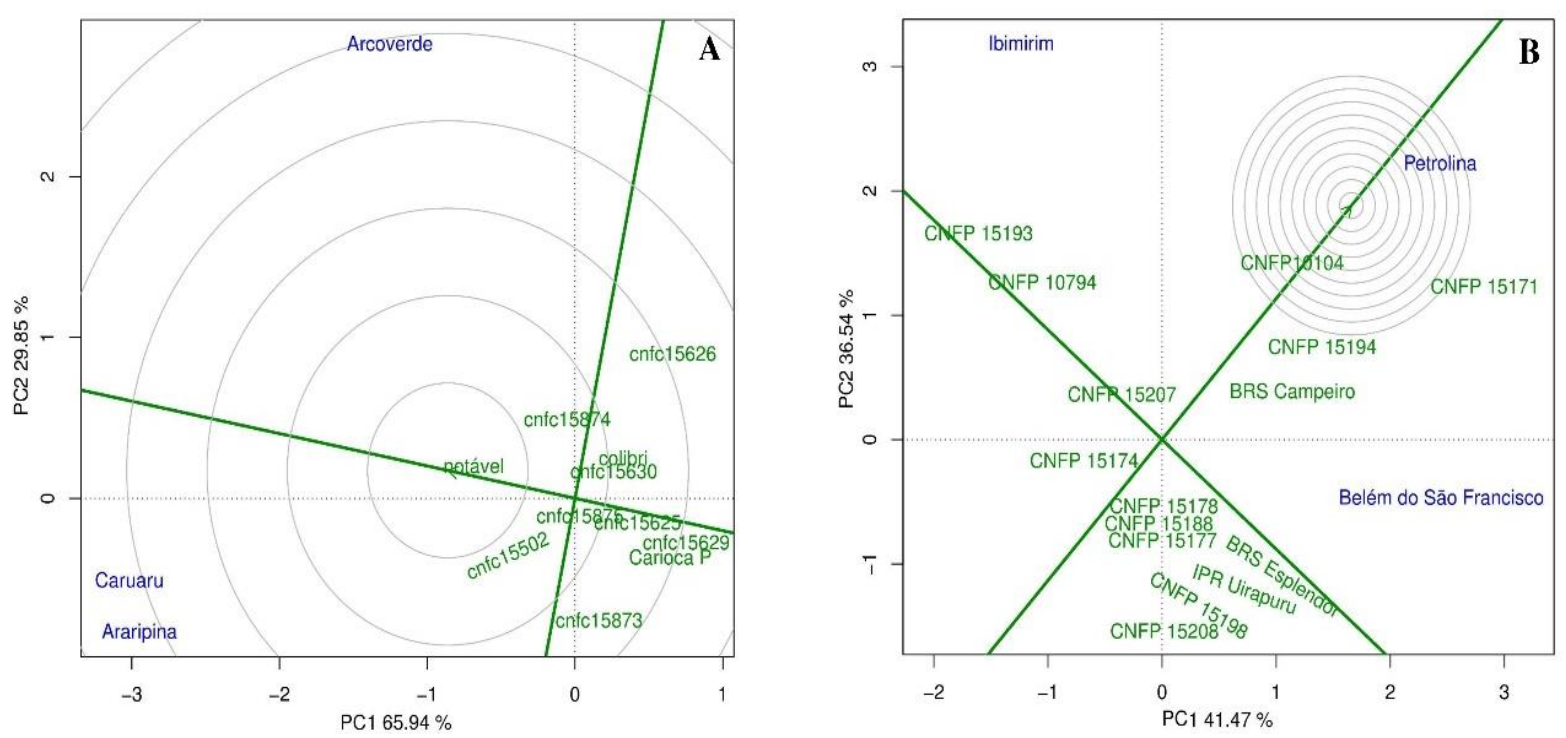

Fig 3. (A) GGE Biplot representing ideal genotype. Genotypes: IPR Colibri, CNFC 15626, CNFC 15873, CNFC 15874, CNFC 15502, CNFC 15875, CNFC 15629, BRS Notável, CNFC 15630, Early 'Carioca', and CNFC 15625. Environments: Arcoverde, Caruaru, and Araripina. (B) Genotypes: BRS Esplendor, BRS Campeiro, IPR Uirapuru, CNFP10104, CNFP 10794, CNFP 15171, CNFP 15174, CNFP 15177, CNFP 15178, CNFP 15188, CNFP 15193, CNFP 15194, CNFP 15198, CNFP 15207, and CNFP 15208. Environments: Ibimirim, Belém do São Francisco, and Petrolina.

Table 4. Municipality characteristics where the 'Carioca' and black bean groups were evaluated.

\begin{tabular}{|c|c|c|c|c|}
\hline \multicolumn{5}{|c|}{-------------------Early ‘Carioca’ Bean----------------- } \\
\hline Environment & Topography & $\stackrel{\circ}{\circ}$ & $\mathrm{mm}$ & Soil Type \\
\hline Caruaru & Wavy & 24 & 551 & Neossoil \\
\hline Arcoverde & Wavy & 23 & 800 & Regolith Neossoils \\
\hline Araripina & Smooth-wavy & 23.7 & 719 & Plain soil \\
\hline \multicolumn{5}{|c|}{ 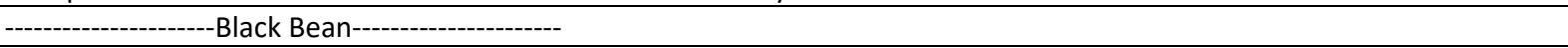 } \\
\hline Ibimirim & Wavy & 25.7 & 866.3 & Litholic stony \\
\hline Belém São Francisco & Smooth-wavy & 24.7 & 507 & Plainsoil \\
\hline Petrolina & Smooth-wavy & 26.9 & 483 & Plainsoil \\
\hline
\end{tabular}



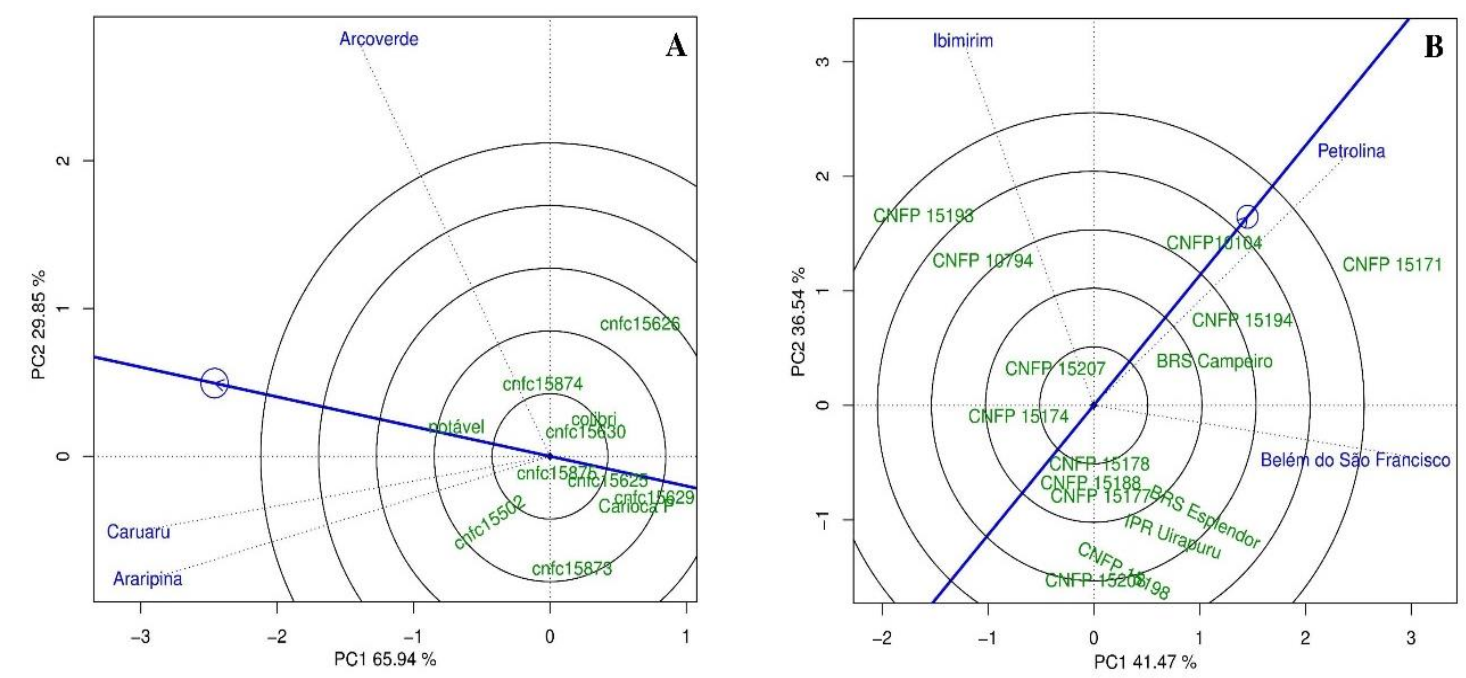

Fig 4. (A) GGE Biplot representing Discrimination and representativeness of the environments. Genotypes: IPR Colibri, CNFC 15626, CNFC 15873, CNFC 15874, CNFC 15502, CNFC 15875, CNFC 15629, BRS Notável, CNFC 15630, Early 'Carioca', and CNFC 15625. Environments: Arcoverde, Caruaru, and Araripina. (B) Genotypes: BRS Esplendor, BRS Campeiro, IPR Uirapuru, CNFP10104, CNFP 10794, CNFP 15171, CNFP 15174, CNFP 15177, CNFP 15178, CNFP 15188, CNFP 15193, CNFP 15194, CNFP 15198, CNFP 15207, and CNFP 15208. Environments: Ibimirim, Belém do São Francisco, and Petrolina.

environment, such as the CNFC 15626 and CNFC 15629 'Carioca' bean line (Figure 1A) and the CNFP 15171 and CNFP 10104 black bean (Figure 1B) (Paramesh et al., 2016). Concerning, the genotypes that are within the polygons, they have lower performance when compared to the vertex genotypes (Oliveira et al., 2018).

\section{Means $x$ stabilities}

The genotype stability is evaluated in the "mean x stability" Biplot, where the circle represents the average environmental coordination (AEC), in which the ideal environment is shown by the line that cuts the origin, and the arrow indicates the highest yield (Yan, 2001) (Figure 2). Moreover, it can be noticed the genotypes that presented good stability by means of the length of the projection formed from the $Y$ axis to the line.

Notwithstanding the variations that may affect the environment, it is seen that the stability is achieved by the BRS Notável control, which performed yield above the overall mean, followed by the CNFC 15874, CNFC 15502, and CNFC 15875 lines, for the 'Carioca' bean group, also classified as stable (Figure 2A). Likewise, the black bean group assigned the CNFP 15171 line as yield above the overall mean; nevertheless, it was considered as unstable (Figure 2B). On the other hand, the CNFP 10104, CNFP 15194, and BRS Campeiro lines provided yields close to the overall mean and good stability (Figure 2B). In accordance with, Nunes et al. (2014), the genotypes that offered the greatest predictability are the most recommended for small rural producers, who do not use much advanced technology.

\section{Ideal genotype}

The genotype considered to be ideal, used as a reference to evaluate the others, is the one that represents the largest vector length and zero GXE interaction, it means the one closest to the center (Santos et al., 2017, Oliveira et al.,
2018) (Figure. 3). Therefore, the CNFC 15874 and CNFC 15502 lines are the most significant for the breeding program, for the 'Carioca' bean group (Figure 3A). Similarly, the black group presented the CNFP 10104 and CNFP 15171 lines as the most relevant, being regarded as the ones closest to the ideal (Figure 3B).

\section{Discrimination and representativeness of the environments}

The discrimination of the tested environments and the capability of representativeness are essential measures to evaluate whether environments provide information about genotypes and whether they are reliable on the genotypes tested, respectively. These measures can be visualized in the graph named "Discriminant vs Representative" (Figure 4). The environments that made smaller angles with the coordination of the environment are the most representative, and the ones that have smaller vectors are those that best described the genotypes (Oliveira et al., 2018). It can be verified that Caruaru and Petrolina formed the environments with the best representativeness and discriminations for the genotypes of the 'Carioca' and black group, respectively (Figures $4 \mathrm{~A}$ and $4 \mathrm{~B}$ ).

\section{Materials and Methods}

\section{Description of genotypes and characteristics of municipalities}

In 2012 crop year, 15 genotypes of black bean group (11 early and semi-early lines and three controls) were evaluated, and, in 2016, 11 genotypes of 'Carioca' bean group (eight early and semi-early lines and three controls) (Table 3) were evaluated, both at the experimental stations of the Instituto Agronômico de Pernambuco - IPA (Pernambuco Agronomic Institute). The black group was evaluated in the municipalities of Ibimirim, Belém do São Francisco, and Petrolina, and the 'Carioca' group, in the 
municipalities of Caruaru, Arcoverde, and Araripina (Table 4).

\section{Experimental design}

The experiment was conducted using a randomized block design with three replicates, totaling 99 experimental units for the 'Carioca' group and 135, for the black one. Each plot comprised four $4-\mathrm{m}$ rows, spacing $50 \times 20 \mathrm{~cm}$, totaling a population of 100 thousand ha-1 plants. Productivity data were collected in the two central lines, disregarding the border lines.

\section{Agronomic practices}

Before implementing the experiments, a soil analysis was performed, in which the sowing fertilization was applied (200 kg.ha-1 of chemical fertilizer 04-20-20, in accordance with Cavalcante, (2008)). Soil was prepared, in a conventional way, by a single plow and two light screenings; the weed control was made by manual weeding. For pest control, the methamidophos insecticide was applied at a dose of $0.5 \mathrm{~L} \mathrm{ha}^{-1}$ every week, in order to control thrips and whitefly, 7 to 50 days after plant emergence, using a manual knapsack sprayer (Boiça Júnior et al., 2000). When it was needed, a supplementary irrigation was carried out by a conventional sprinkler system.

\section{Statistical analysis}

\section{Variance homogeneity}

The grain yield variable collected during the early 'Carioca' bean and black bean trials were submitted initially to the analysis of variance homogeneity (Bartlett Test) and normality (Lilliefors). Given that the variances were homogeneous and normal, analyses of variance were applied with no need for transformation. After that, it was performed a relationship test between the maximum and the minimum residual mean square of the environments $\left(\mathrm{RMS}_{\mathrm{Max}} / \mathrm{RMS}_{\mathrm{Min}}\right)$, which were lower than seven for the early 'Carioca' bean (2.67) and black (1.60) trials, enabling the joint analysis of the trials.

\section{Joint analysis}

The joint analysis of variance was conducted, regarding the effects of genotypes, environments, genotype $x$ environment interaction, applying the following statistical model: $\quad \bar{Y}_{i j k}=\mu+G_{i}+B / A_{j k}+A_{j}+G_{i j}+\varepsilon_{i j k}$ in which $\bar{Y}_{i j k}=$ observation of the genotype $i(i=1,2 ., g)$, in the environment $\mathrm{j}(\mathrm{j}=1,2$..env), in block $\mathrm{k}(\mathrm{k}=1,2, \ldots, \mathrm{b}), \mu=$ overall mean of the trial, $\mathrm{G}_{\mathrm{i}}=\mathrm{i}$-th genotype $(\mathrm{i}=1,2, \ldots$, $\mathrm{g}), \mathrm{B} / \mathrm{A}_{\mathrm{jk}}=$ effect of the k-th blockin thej-thenvironment $(\mathrm{j}=1$, $2, \ldots$, env $), A_{j}=j$-th environment $(j=1,2$...env $), \mathrm{GA}_{\mathrm{ij}}=$ genotype environment interaction, $\varepsilon_{\mathrm{ijk}}=$ experimental error associated to the observation $\overline{\mathrm{Y}}_{\mathrm{ijk}}$.

\section{GGE Biplot}

The GGE Biplot analysis was made on the basis of the phenotypic means according to the following model: $\bar{Y}_{i j}-$ $\mu-A_{j}=G_{i}+G_{i j}$, in which $\bar{Y}_{i j}$ represents the phenotypic mean of the genotype $i$ in the environment $j, \mu$ is the overall constant, $G_{i}$ is the aleatory effect of the genotype $i, A_{j}$ is the fix effect of the environment $j$, andGA $A_{i j}$ is the aleatory effect of the interaction between the genotype $i$ and the environment $\mathrm{j}$.

The GGE Biplot model does not separate the effect of genotype $(G)$ from the genotype-environment interaction (GE), keeping them together in two multiplicative terms, which can be seen in the next equation: $\bar{Y}_{i j}-\mu-\beta_{j}=$ $\mathrm{g}_{\mathrm{i} 1} \mathrm{e}_{1 \mathrm{j}}+\mathrm{g}_{\mathrm{i} 2} \mathrm{e}_{2 \mathrm{j}}+\varepsilon_{\mathrm{ij}}$, in which $\bar{Y}_{i j}$ is the expected performance of the hybrid $i$ in the environment $j ; \mu$ is the overall mean of the observations; $\beta_{j}$ is the main effect of the environment j; $g_{i 1}$ and $e_{1 j}$ are the main scores for the $\mathrm{i}$-th hybrid in the $\mathrm{j}$-th environment, respectively; $g_{i 2}$ and $e_{2 j}$ are the secondary scores for the $\mathrm{i}$-th hybrid in the $\mathrm{j}$-th environment, respectively; $\varepsilon i j$ is the residue unexplained by both effects.

In this manner, the Biplot graph design in the GGE model is done by the simple dispersion of $g_{i 1}$ and $g_{i 2}$ for genotypes and $e_{1 j}$ and $e_{2 j}$ for environments via Singular Value Decomposition (SVD), according to the equation: $\mathrm{Y}_{\mathrm{ij}}-\mu-$ $\beta_{\mathrm{j}}=\lambda_{1} \xi_{\mathrm{i} 1} \eta_{\mathrm{ij}}+\lambda_{2} \xi_{\mathrm{i} 2} \eta_{2 \mathrm{j}}+\varepsilon_{\mathrm{ij}}$, in which $\lambda_{1}$ and $\lambda_{2}$ are the highest eigenvalues of the first and second principal components $\mathrm{PC} 1$ and $\mathrm{PC} 2$, respectively, $\xi_{i 1}$ and $\xi_{i 2}$ are the eigenvalues of the $\mathrm{i}$-th genotype for PC1 and PC2, respectively, $\eta_{i j}$ and $\eta_{2 j}$ are the eigenvalues of the $\mathrm{j}$-th environment for $P C 1$ and $P C 2$, respectively.

\section{Software}

The GGE Biplot analyses were conducted using the $R$ software ( $R$ Development Core Team, 2014) using the GGE Biplot GUI package in $R$ software (Wickham, 2009). Differences between cultivars and lineages were also investigated by the Tukey's test at 5\% probability, using the computational resources of the Genes program (Cruz, 2013).

\section{Conclusion}

The GGE Biplot methodology was found to be efficient in identifying genotypes with good adaptability, stability, and yield. The analyses confirmed the BRS Notável cultivar and the CNFC 15874 line for the Araripina and Caruaru environments should be cultivated. For Arcoverde, the CNFC15626 line was shown to be superior to the others. For the black group, the CNFP15171 and CNFP10104 lines provided the best performance for Belém do São Francisco and Petrolina municipalities. The CNFP 15193 and CNFP 10794 lines were selected for the Ibimirim environment.

\section{References}

Badu-Apraku B, Oyekunle M, Obeng-Antwi K, Osuman AS, Ado SG, Coulibay N, Didjeira A (2012) Performance of extra-early maize cultivars based on GGE biplot and AMMI analysis. The Journ of Agric Scien. 150(4): 473-483. Barros MA, Rocha MM, Gomes RLF, Silva KJD, Neves AC (2013) Adaptabilidade E Estabilidade Produtiva De FeijãoCaupi De Porte Semiprostrado. Pesq Agropec Bras. 48: 403-410. 
Bertoldo JG, Coimbra JLM, Guidolim AF, Nodari RO, Elias HT, Barili LD, Vale NM And Rozzetto DS (2009) Rendimento de grãos em feijão preto: o componente que mais interfere no valor fenotípico é o ambiente. Ciênc Rur. 39: 1974-1982.

Boiça Júnior, AL, Muçouçah, MJ, Santos, TM And Baumgartner, JG (2000) Efeito de cultivares de feijoeiro, adubação e inseticidas sobre Empoasca kraemeri Ross \& Moore, 1957 e Bemisia tabaci (Gennadius, 1889). Acta Scient. 22: 955-961.

Coimbra JLM, Barili LD, Vale MN, Guidolin AF, Bertoldo JG, Rocha F, Toaldo D (2008) Seleção para caracteres adaptativos em acessos de feijão usando REML/BLUP. Magis. 20: 177-185.

Companhia Nacional de Abastecimento - CONAB (2019) Acompanhamento da safra brasileira de grãos: monitoramento agrícola safra 2018/2019. Brasília: Conab. 6 (8): 46.

Cruz CD, Torres RAA, Vencovsky R (1989) An alternative approach to the stability analysis proposed by Silva and Barreto. Revis Brasi de Genét. 12: 567-580.

Cruz CD (2013) GENES: a software package for analysis in experimental statistics and quantitative genetics. Acta Scient Agron 35: 271-276.

Eberhart SA, Russell WA (1966) Stability parameters for comparing varieties. Crop Scien. 6: 36-40.

FAO (2015) Base de dados de produção. FAOSTAT, Accessed on: http://www.fao.org/home/en/. Accessed: february (2018).

Lin CS, Binns MR (1988) A superiority measure of cultivar performance for cultivars $x$ location data. Canad Journ of Plant Scien. 68: 193-198.

Nunes HF, Freire Filho FH, Ribeiro VQ, Gomes RLF (2014) Grain yield adaptability and stability of blackeyed cowpea genotypes under rainfed agriculture in Brazil. Afric Journ Agricul Resear. 9: 255-261.

Oliveira TRA, Gravina GA, Oliveira GHF, Araújo KC, Araújo LC, Daher RF, Vivas M, Gravina LM and Cruz DP (2018) The GT biplot analysis of green bean traits. Ciên Rur. 48: 1-6.

Paramesh M, Reddy DM, Priya MS, Sumathi P, Sudhakar P and Reddy KHP (2016) GT biplot analysis for yield and drought related traits in mung bean (Vigna radiata $\mathrm{L}$. Wilczek). Electr Journ of Plant Breed 7: 538-543.

Paranzini Faria A, Moda-Cirino V, Sawada Buratto J, Borges da Silva C, Destro D (2009) Interação genótipo $x$ ambiente na produtividade de grãos de linhagens e cultivares de feijão. Acta Scienti Agron. 31(4).
Pereira MG, Catarina RS, Ribeiro EH and Miranda JM (2018) UENF 2014: a new common bean cultivar. Crop Breed and Appl Biotechn.18: 126-129.

Ribeiro ND, Dalfollo N, Antunes IF, Souza JF and Poersch NL (2008) Adaptação e estabilidade de produção de cultivares e linhagens-elite de feijão no Estado do Rio Grande do Sul. Ciên Rur. 38: 2434-2440.

Rosse LN, Vencovsky R (2000) Modelo de regressão não linear aplicado ao estudo da estabilidade fenotípica de genótipos de feijão no Estado do Paraná. Bragan. 59: 99107.

Santos A, Amaral Júnior AT, Kurosawa RNF, Gerhardt IFS, Fritsche Neto R (2017) GGE Biplot projection in discriminating the efficiency of popcorn lines to use nitrogen. Ciên e Agrotecn. 41: 22-31.

Silva OF, Wander AE, (2013) O feijão-comum no Brasil passado, presente e futuro. Santo Antônio de Goiás: Embrapa Arroz e Feijão. 61.

Torres FE, Teodoro PE, Sagrilo E, Correa AM and Ceccon G (2015) Interação genótipo $\times$ ambiente em genótipos de feijão-caupi semiprostrado via modelos mistos. Bragant. 74: 255-260.

Torres Filho J, Oliveira CNGS, Silveira LM, Nunes GHS, Silva AJR and Silva MFN (2017) Genotype by environment interaction in green cowpea analyzed via mixed models. Revis Caatin. 30: 687-697.

Verma VMM, Chahal GS and Murty BR (1978) Limitations of conventional regression analysis a proposed modification. Theor and Appl Genet. 53: 89-91.

Watanabe IA, Silva FC, Pereira HS, Melo LC, Faria LC, Souza TL, Magaldi MC (2014) Avaliação da qualidade comercial dos grãos de linhagens de feijoeiro-comum carioca com ciclo precoce. In Embrapa Arroz e Feijão-Artigo em anais de congresso (ALICE). In: Congresso Nacional de Pesquisa de Feijão, 11., 2014, Londrina. Tecnologias para a sustentabilidade da cultura do feijão: anais. Londrina: IAPAR.

Wickham H (2009) GGPLOT 2: Elegant Graphics for Data Analysis. Springer-Verlag. New York. 182.

Yan W (2014) Crop variety trials: Data management and analysis. John Wiley \& Sons. 360.

Yan Weikai (2001) GGE Biplot a Windows application for graphical analysis of multienvironment trial data and other types of two-way data. Agron Journ. 93 (5): 11111118.

Yokomizo GKI, Farias Neto JT, Hongyu K, Oliveira MDSP (2017) GGE Biplot na avaliação de características de cachos em açaizeiros da região amazônica. Mund Amaz. 8: 1-16. 